\title{
In the sedimentary distribution of Lishu fault
}

\author{
YAN Di ${ }^{1, a}$; YUAN Hongqi ${ }^{2, b}$; JiangZheng ${ }^{3, ~ c ~}$ \\ ${ }^{1}$ Northeast Petroleum University of Daqing City, Heilongjiang province in China \\ ${ }^{2}$ Northeast Petroleum University of Daqing City, Heilongjiang province in China \\ ${ }^{3}$ JiangZheng Daqing Oilfield Of Cnpc No.5 Oil Production Plant No.1 Oil Deposit

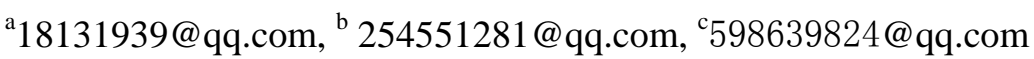

Keywords:Pear sag, classification and correlation, stratigraphic distribution characteristics

\begin{abstract}
Pear cretaceous fault depression region based on predecessors' study of sequence stratigraphy, in combination with regional sedimentary data, combining well logging, core data to study the distribution features of sequence stratigraphy in this area. Sign and use logging curve characteristics and the lithology of denglouku group and city, city group and shahe subgroups, shahe group and fire stone mountain, for stratigraphic division and stratigraphic classification results were summarized. Finally, the paper describes the distribution characteristics of pear trees faulted strata.
\end{abstract}

\section{Regional geological survey}

Pear sag is located in the southeast uplift area, songliao basin is a composite basin superimposed fault depression, east of tanlu fault zone, pear, gongzhuling across two city, covers an area of about $2300 \mathrm{~km} 2$, mining area resources 360 million tons of oil equivalent, 205 opening of exploratory well, the whole sag found nine oil and gas fields, proven oil reserves of 44.3585 million tons, proven degree is 20.6\%; Proven gas geological reserves of 19.341 billion square, the proven degree is $13.5 \%$. Is divided into four secondary structural belt, the Northern Slope zone, steep slope zone, the central structural belt, west slope area in the east. Its overall assumes the north north east to distribution, for the west boundary mulberry big fracture controlled by west fault ne "basket" of the early cretaceous fault depression, western formation sedimentary thickness is big, the nearly $10000 \mathrm{~m}$ thick, east side of the boundary faults development, stratigraphic overlap upwards, thickness thinning, even pinchout (YuKai etc., 2000; Jia Hongwei etc., 2004; yu-ming chang, 2006). Pear fault is a composite fault depression of superimposed basin (Zhang Kai etc., 1989; QinSuHua etc., 2003), the fault structural layer by fire stone mountain (K1h), shahe group (K1sh), city (K1yc) and denglouku group (K1d), average thickness of more than $5 \mathrm{~km}$; Upper depression structural layer is thin, generally is about $2 \mathrm{~km}$, from quantou formation (K1q), qingshankou formation (K1qn) and nenjiang group (K1n), lack of the quartet group one MingShui group. Bottom-up found lower cretaceous shahe subgroups (four or five subsidiary of oil and gas layer), the city group (five subsidiary of oil and gas layer), the denglouku group (small oil and gas layer), quantou formation (agriculture, oil and gas layer, Yang DaChengZi oil and gas layer) and other five oil and gas formation (liu small equality, 2010) 


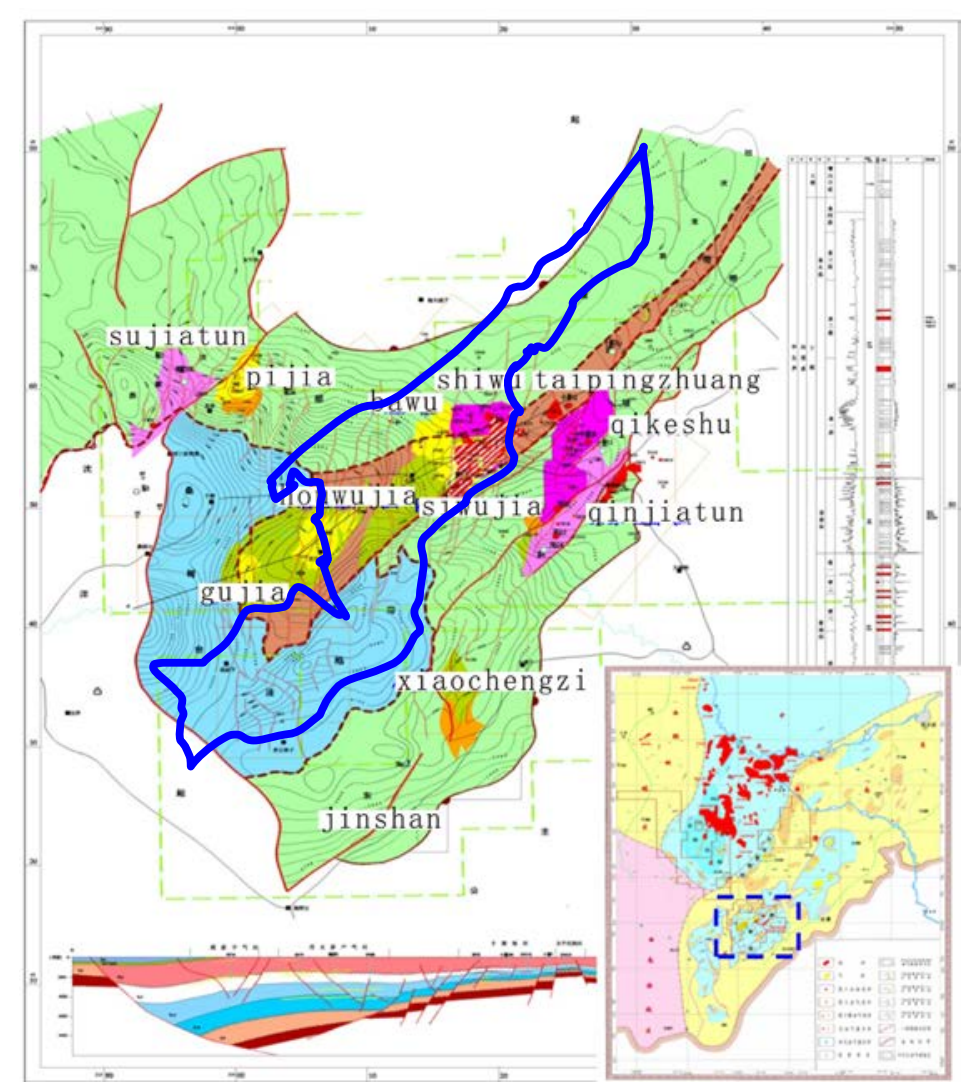

Figure 1 pear trees in the study area

\section{Stratigraphic classification and correlation}

2. 1 stratigraphic classification and correlation

\subsection{1 logging curve}

(1) curve of denglouku group and city symbol: the top of denglouku formation and its underlying set of battalion city group sandstone formation resistivity curve and acoustic curve between the baseline change is more obvious, embodied in denglouku group is low resistivity curve overall characteristics, sandstone resistivity under the tooth the peak has the formation law of low FuYing city group. City group sandstone resistivity teeth peak value is higher. In addition, look from the acoustic curve, denglouku group camp on the whole city for high background values, low acoustic baseline values.

(2) city group and shahe subgroups curve marks: at the bottom of the city group camp a sandstone development degree is low, lower than sand, waves as high value of response of the large set of mudstone, and underlying subgroups formation at the top of the sand river sandstone development degree is higher, the sand ground is higher, sound wave curve for large sets of low response. The interface characteristics is very clear, drilling basically has the characteristics of the whole district.

(3) the curve marks: shahe subgroups and fire stone mountain group in the fire drill in shahe subgroups and stone mountain formation boundaries fewer Wells, drilling case of stone mountain formation thickness larger only gold 2 Wells, the fire stone mountain mudstone as dark gray, the overlying shahe subgroups formation mudstone as the gray, fire stone mountain formation sandstone is gray, and shahe subgroups is gray. 


\subsection{2 lithology logo}

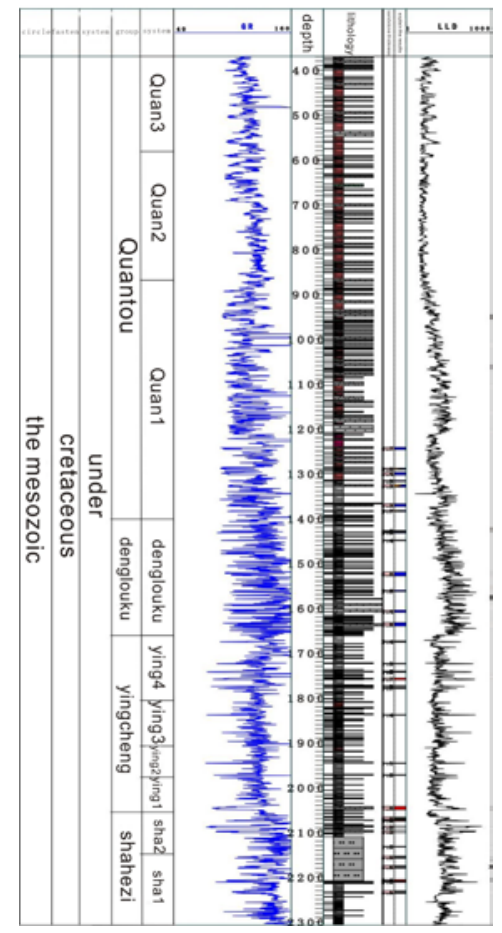

Look from the north-south even well profile, denglouku group as a whole sand ground is higher, conglomeratic sandstone, mudstone background for purple, purple. In general, the area from the fire stone mountain group and denglouku group, the strata of well logging curve logo more clear, the only change in local.

\section{3 pear faulted strata distribution characteristics}

Pear sag downfaulted layer fire stone mountain group of the residual thickness of about 2100 $\mathrm{m}$ or so, in the fault depression in the Midwest, mulberry fracture SN86 Wells near on the east side; Minimum residual thickness of only a few meters, are mainly distributed in northeast sag and north-central. Shahe subgroups the residual thickness of about $2500 \mathrm{~m}$, is located in the fracture of the Midwest, shahe child period sedimentary range from fire stone mountain period decreased significantly, the secondary with the sedimentary thickness of the main acceptor fracture control or influence, on the whole from Midwest to east, north and south gradually thinning.

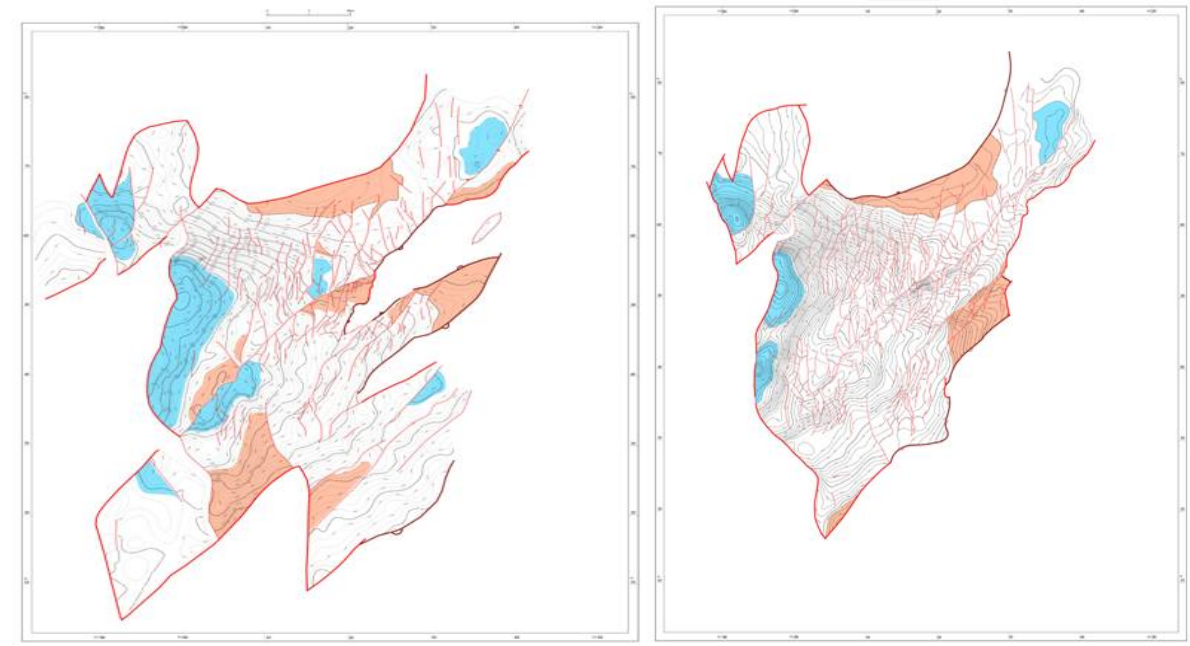




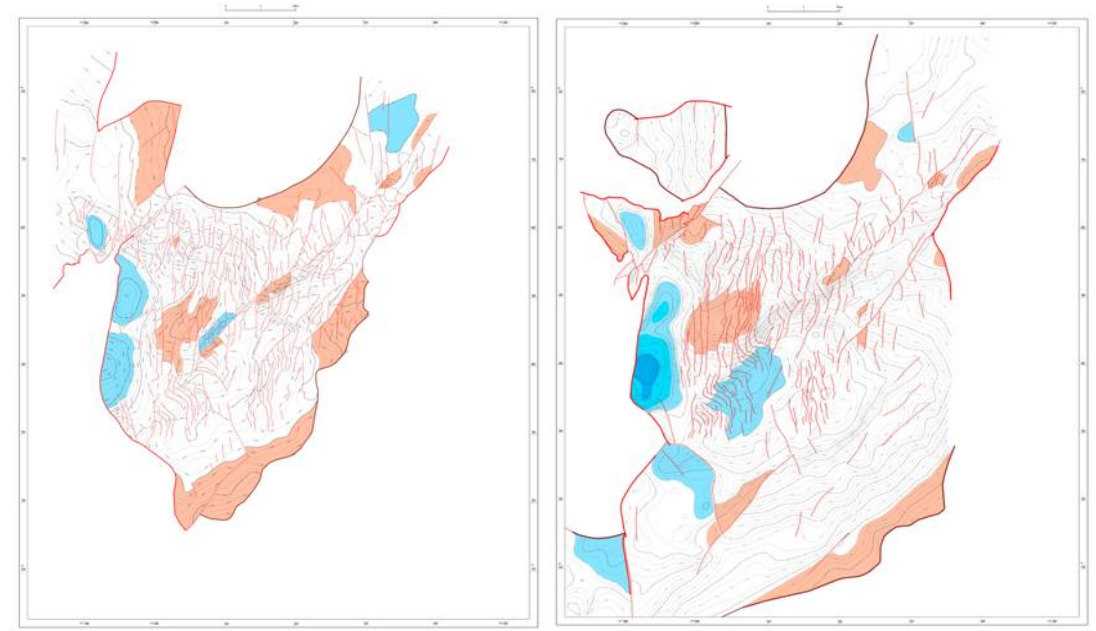

Figure 2 Pear tree phase fault fault depression at the top of the stratigraphic structure diagram (2010) according to the northeast branch of reproduction

\section{Summary}

(1) using the log marks, lithology for stratigraphic classification and correlation, and improve the precision of sequence stratigraphy.

(2) the sequence stratigraphy is divided into four, spring three springs, spring 2, paragraph, denglouku group, camp four, three, sand, sand paragraph 9 secondary sequence.

(3) fine description fire stone mountain, shahe, city group and denglouku group of stratigraphic distribution characteristics of times.

\section{References:}

[1] Yu-shuang hu, ming-xue zhang. Pear songliao basin rift sedimentary evolution and sequence stratigraphy models [J]. Journal of daqingOil school journal, 1999, 23 (1).

[2] guo or high flat, cattle, etc.In the southern songliao basin pear area reservoir forming geological conditions research [J].Journal of oilAnd natural gas geology, 1992,13 (3).

[3] Li Mingcheng, hydrocarbon migration theory and oil and gas exploration [J], earth science, 2004, 29 (4):379-383.

[4] Shimizu,dong zhao of silver, liu jun,etc.Half graben faulted basin type of hydrocarbon accumulation pattern - pear fault depression in songliao basin as an example [J], journal of jilin university (earth sciences), 2003 (1):43-47.

[5] Mr.Luo,LuHong, pear depression fracture characteristics and control of the oiland gas [J], journal of daqing petroleum institute, 1996, 20 (3):6-10.

[6] Zou,lj;jia,wen-zhizhao, etc. In southern songliao basin accumulation Dynamicsand distribution of lithostratigraphic reservoirs [J],oil exploration and development, 2005,32 (4):125-130. 